Journal of Social Sciences 8 (3): 381-389, 2012

ISSN 1549-3652

(C) 2012 Science Publications

\title{
Understanding of the Built of European Union Legal System: The Function of Individual Rights
}

\author{
Valentina Colcelli \\ Department of Juridical Studies, \\ Faculty of Law, University of Perugia, Via Pascoli, Italy
}

\begin{abstract}
The article analyses whether in the EU legal system, the selection of relevant interests in horizontal legal relationships arises for the same reason and in the same way as the qualification of rights in vertical legal relationships, that is, to consolidate the EU legal system. It analyses the network of private actors and the relations among them within the EU legal order. Familiar private law instruments such as tort or contract now appear as only a small part of many possible tools harnessed with the aim of obtaining allocative efficiency or distributive justice and are synthetically described as the correction of market failures.
\end{abstract}

Key words: Horizontal legal relationships, examines examples, structure internal market, competition rules, first necessary, Draft Common Frame of Reference (DCFR)

\section{INTRODUCTION}

Moving from the Al-Swelmeen (2006) paper and his idea to understand the structure of international law as part of interior system, the article analyses the particular relation between legal protection within the European Union (EU) legal system and the qualification of individual rights in vertical and horizontal legal relationships in order to understand the peculiarities of the EU legal system.

This study is not a taxonomy of horizontal relations but an examination of examples drawn from competition law, remedies for State liability, or the effet utile (useful effect). These are used to demonstrate broader conceptual claims: in the EU legal system, the selection of relevant interests in horizontal legal relationships arises for the same reason and in the same way as the qualification of rights in vertical legal relationships, that is, to consolidate the EU legal system.

To achieve these aims, it is first necessary to analyze the methods adopted by the EU legal system to qualify individual rights, because, in this system, individual rights may not be handled without analyzing legal remedies and the systems for their protection.

Thus, with regard to the structure of EU law as part of an interior system, it is possible to analyze the network of private actors and the relations among them within the EU legal order. It is possible to assess that in the EU legal system, the selection of relevant interests in horizontal legal relationships occurs in the same manner and for the same purpose as the qualification of rights in vertical ones: the structuring of internal markets and pursuance of the primauté of the EU.

Build of the European Union: the function of typical principles of private law: All European Union laws regulate relationships-whether vertical or horizontal-but not generic relations. These relationships aim to pursue the primauté of the EU and conserve its legal system and internal market and, in horizontal relationships, to consolidate the EU legal system-initially structured by the regulation of vertical relationships.

Therefore, although relationships between individuals concerning contractual rights and obligations emerged in the EU legal system later, they are required to perform the same function reserved for individual rights in vertical relationships.

Because of the close functional relationship between legal protection and substantive rights in the EU legal system, integrating this system with national courts strengthens the above considerations (paragraph 3 ) and extends results achieved in terms of the function and nature of non-application from vertical relationships with horizontal ones. In both relationships, non-application is a tool of control at the disposal of Member States that may be used for transposing Directives into national law.

National laws are inapplicable if they conflict with the effects envisaged by EU rules (paragraph 3 ). This is especially true in cases where the time for protection through non-disapplication is anticipated with respect to the moment of the transposition of a Directive containing technical standards and regulations 


\section{J. Social Sci., 8 (3): 381-389, 2012}

(paragraph 5). This happens when Member States exercise weak discretion. In other words, in horizontal relationships, a national legislation contrary to a Directive whose period for transposition has not expired need not be applied (paragraph 6).

The Court of Justice provides an additional interpretation of non-contractual liability in horizontal relationships. Such a liability ensures that EU law is fully effective, as it is in vertical relationships (paragraph 7).

Today, the fact that one can trace a trend to the uniform definition of non-contractual liability in EU law reinforces EU judge's logic that infringement of EU rules aimed to conserve its legal system (carried out by individuals against other individuals) means ensuring the effet utile of EU rights (paragraph. 3).

The EU discipline of competition may be interpreted in this sense: Anti-competitive business practices that have a direct impact on final consumers are prohibited. Thus, consumers may be compensated for damages caused to them by businesses infringing EU competition rules.

Expanding the number of persons protected by EU legislation on competition, including consumers, is a way of enhancing the use of non-contractual liability and preserving the effectiveness of internal markets as competitive structures. This is perhaps the aspect that most greatly emphasizes the trend, applicable also to horizontal relationships, which the EU Court highlighted: actions for damages (for non-contractual liability) are a measure to ensure the full effectiveness of EU rights.

As mentioned above, The EU legal system has also two typical civil law principles, the recovery of sums paid but not due and contract liability, which are aimed at guaranteeing that the economic order sought by the Union is maintained (paragraphs 6 and 7).

Therefore, horizontal relationships in the EU legal system, in view of the functions assigned to legal protection, are selected and adjusted to ensure the existence and survival of the EU legal system. Relationships are aimed at conserving the legal system which was established by the Treaties and which, even within the interstices of the rules, the Court of Justice originally encoded and continues to interpret.

Legal protection and qualification of individual rights in the EU legal system: Protection of individual rights national/EU Courts is the best method for EU integration. To guarantee the existence of the EU legal system, the Court does not rely on Members States but attributes subjectivity to individuals instead. Attributing subjectivity to individuals and providing remedies (by the Court) is another measure to strengthen the Community primauté. The European Court of Justice, which symbolizes the existence of the EU legal system, uses the strategy of declaring the rights of individuals to ground their constitutional intuition.

By recourse to courts and implementation of remedies, individuals become the principal guardians of EU Law.

Originally, the Court of Justice played a principal role in qualifying EU individual rights. Between 1960 and 1970-its early period of operation-the Court of Luxembourg used Schutznormtheorie to identify individual rights against European Institutions, which recognized legal positions without distinguishing between substantive rights and interests. At the same time, the Court of Justice used the principle of direct effect to identify individual rights against Member States.

This approach is no longer applied. Because the competences of the Community were increasing in a functional way in order to reach the internal market, it was very difficult to identify new individual rightscreated during the expansion of Community powers-by applying the aforementioned theories.

Therefore, the Court of Justice subsequently used the principle of useful effect to identify individual rights against Member States, which thus became debtors of the individual. After the Francovich judgement, the qualification criteria for selecting individual rights changed (Bartolini, 2005).

The Court uses the idea, borrowed from the common law tradition, that remedies are one of the selection methods of significant subjective interest in the EU legal system. Remedies-measures to qualify individual rights-follow the classical system of qualification of individual rights in civil law, in which rights are expressed as rules.

Recourse to remedies goes beyond the continental approach, which posits that the significance and effectiveness of individual rights depend on rules. Thus, individual rights are qualified when the judges apply rules concreting and conforming to the objectives pursued by the Community.

National courts: the first system of legal protection of EU individual rights: In the $\mathrm{EU}$, national courts protect individual rights in horizontal and vertical relationships. However, EC Treaties (in particular, the Treaty on the functioning of the European Union) and EU Treaties have made 'a number of instances of private persons bring a direct action, where appropriate, before the Court of Justice, (...) not intended to create new remedies in the national courts to ensure the 


\section{J. Social Sci., 8 (3): 381-389, 2012}

observance of Community law other than those already laid down by national law' (Rewe v Hauptzollamt Kiel (C- 158/80), [1981] ECR, 1805).

In a notice issued on 13 February 1993 on cooperation between national courts and the Commission in applying Arts. 85 and 86 of the EEC Treaty ([1993] OJ C39/6.), the EU Commission explains that in the same conditions that Member States apply in the case of violation of domestic rules, natural persons and enterprises are entitled to access all legal remedies provided by Member States.

Referring to the question of Arts. 105 and 106 of the Treaty on the functioning of the European Union (Arts. 85 and 86 of the EC Treaty), the Commission stated that this equality treatment between domestic and Community rights concerns not only the final declaration of violation of competition rules but also, in order to promote effective judicial protection, all EU rights.

EU individual rights, to accord them equal treatment with national individual rights, are legally protected by national courts in view of the relationship between directly applicable Community rules and the system of national legal sources, this is unsurprising.

With regard to the EU legal system, individual rights can be effectively protected only if they are used in actions before national courts (Theresa Emmot $v$ Minister for Social Welfare, (C-208/90) [1991] ECR, I4269). It is for 'the legal system of each Member State to determine which court has jurisdiction to hear disputes involving individual rights derived from Community law, but at the same time the Member States are responsible for ensuring that those rights are effectively protected in each case' (Theresa Emmot v Minister for Social Welfare, (C-208/90), cited).

When the national system of protection cannot guarantee Community rights sufficiently, the equipment provided by the EU legal system comes into action. In the system, a uniform network of safeguards of Community individual rights (e.g., liability of a Member State, recovery of sums paid but not due, disapplication and obligation to interpret national law in conformity with Community law) is provided for when the judiciary of a Member State does not safeguard the effectiveness of the protection of Community rights. The system envisages not specific or special protection for individual rights but provisions by Member States for effective national legal protection.

The Court is not interested in whether or not different jurisdictions of Member States guarantee extremely high-level legal protection or better legal protection than each other. To ensure that Community rights are effectively protected, national legal protection cannot be lowered below the minimum standard of necessary safeguards. If and/or when this happens, the aforementioned equipment is utilized.

Thus, the judiciaries of the Member States ensure the supremacy as well as effectiveness of Community law.

The primauté of EU law: an attempt to jointly reconstruct the liabilities in horizontal and vertical relationships: The system for protecting individual rights, which emerges when the principle of effet utile is applied, is a new way of qualifying individual rights. In accordance with this principle, Member States not fulfilling their obligation to implement Community rules which are not directly applicable are rendered debtors (Gerven, 1993).

In appropriate conditions, private persons are held non-contractually responsible for not respecting the directly applicable Community law.

In the Court of Justice, the liability of private persons, like that of Member States, for infringement of Community law is a measure of guaranteeing that the law is implemented.

This symmetry involves another concept: the criteria guiding actions for damages against Member States may be extended to include actions for damages in relationships between private persons. In this sense, some attention should be paid to liability in horizontal relationships, that is, the provisions of EC Regulation no. 178/2002. For instance, operators of the food chain may be required to compensate damages caused by their products because of not only possible defects in those products but also the breach of the precautionary principle (Art. 19, Reg. no. 178/2002). However, in the EU legal system, infringement by private persons of the precautionary principle in the food chain may be a significant indicator of the possibility of joint reconstruction of compensation for damages.

Advocate-general Van Gerven affirmed this opinion. In his concluding remarks to HJ Banks \& Company Ltd v British Coal Corporation (C-128/92), [1994] ECR I-1212, paragraphs 36-54), he asserted that a significant number of elements could be found in the EU legal case about the Community's liability for qualifying private persons' responsibility in EU law infringement.

In the EU legal system, the first elements of contact between vertical and horizontal liabilities are the rules intended to confer rights on individuals.

The infringement of EU rules, understood as aiming at conferring rights on individuals, is the reason behind compensation claims for damages caused by Institutions, Member States and individuals. 


\section{J. Social Sci., 8 (3): 381-389, 2012}

Among other things, to identify these categories of rules, one must clarify which of them are included in the concept, within the EU legal system, of a rule which confers rights on individuals. Non-contractual liability is thus a litmus test to determine from which EU rules individual rights may be implemented. Principles infringed by Institutions must be higher ranking and should protect individuals. Traditionally, higherranking principles are the general principles of the EU legal system. However, the jurisprudence of the Court of Justice has somewhat advanced. While it traditionally equated the definition of higher rank with general principles, the current trend among Luxembourg judges is different. The Court now uses the same criteria used to configure the non-contractual liability of Member States to qualify the noncontractual liability of the Community (Bergaderm and Goupil v Commission C-352/98 [2000], ECR I-5291). Therefore, such non-contractual liability may be recognized even if the rule breached is not a highranking principle, as described above (See also Bergaderm and Goupil v Commission C-352/98, cited).

In the case of the non-contractual liability of the Community, Art. 263 of the Treaty on the functioning of the European Union (Art. 230 of the EC Treaty) indicates how to find the rules of law intended to confer rights on individuals. Criteria for identifying a higherranking principle are like those for identifying rules for a legal review of institutional acts: the reference is not only general principles but also the Treaty and fundamental principles.

Some judgements of the Court of First Instance are indicative of this (See FIAMM and FIAMM Technologies $\mathrm{v}$ Council of the European Union and Commission (T-69/00), [2005] ECR, II-5393). In six recent judgements, the Court reflected on the value of the WTO agreements. The Court of First Instance stated that these international agreements do not confer rights on individuals. Because of their nature and structure, the WTO agreements are not among those rules by which EU Courts review the legality of action by Community Institutions (Portugal $v$ Council (C149/96), [1999] ECR, I-8395, paragraph 47; the order in OGTFruchthandelsgesellschaft case (C-307/99), [2001] ECR I-3159, paragraph 24). The Court can review the legality of the conduct of the defendant Institutions by WTO rules when the Community intends to implement a particular obligation assumed within the context of the WTO or when the Community measure expressly refers to specific provisions of the WTO agreements (see, as regards GATT 1947, Fediol v Commission (C-70/87), [1989] ECR, 1781, paragraphs 19-22 and, with regard to WTO agreements, Biret
International v Council (C-93/02 P), [2003] ECR, I10497).

Thus, in these judgements, the Court is referring to the meaning of the higher-ranking principle, which, in accordance with Art. 263 of the Treaty on the functioning of the European Union, is among the rules the Court uses in reviewing the legality of EU bodies' measures.

Additionally, in cases of non-contractual liabilities of Member States, when principles designed to confer rights on individuals are not implemented (e.g., Francovich), they are deemed to be directly applicable Community laws (e.g., Brasserie du Pêcheur), not rules.

In private relationships, only directly applicable Community laws confer rights on individuals. This excludes Directives, even self-executing ones.

EU law is not sufficiently equipped to identify the non-contractual liabilities of the Community or Member States and, now, of individuals as well. Serious breaches of rules concerning discretionary power in implementing legislative measures are enforcement measures for non-contractual liabilities of Community or Member States.

In cases where broad discretion is not applied, a simple infringement of Community rights by the Community or Member States can lead to a configuration of non-contractual liability. On the other hand, when instruments of binding secondary legislation do not contain unconditional and sufficiently precise provisions, non-contractual liabilities of Member States or EU Institutions are not configured.

When an Institution does not have discretionary powers strong enough to take legislative measures, the simple failure to fulfil a Community rule can indicate a serious breach of it.

Conversely, when discretionary powers are strong enough, the liability of national authorities does not arise. In these cases, the liabilities of both Institutions and Member States arise only if the liabilities do not originate, as they are required to do, from a legal act. Therefore, this omission implies that they have seriously omitted to carry out a required act.

The EU legal system shows that liability is not related to the nature of any substantive right. Because of the recognition of the right to compensation, the conduct of others-States, Institutions, or individualsaffects the legal position of a private person.

In civil law, EU non-contractual liability may be described as a subjective right to have legal rights remedied if they are damaged. Thus, the noncontractual liability of the Community may be configured even if rules are not infringed. In such a case, the severity of the damages suffered is sufficient 
to make a claim: the breach must be sufficiently serious, that is, a causal relationship must exist between it and the damages suffered by the injured party (Biovilac v Commission (C-59/83), [1984] ECR, 4057, paragraph 28).

Discretionary and non-contractual liability of individuals: Private operators of, for example, the food chain must carefully examine the relationship between discretionary and non-contractual liabilities of Institutions and Member States.

The nature of the precautionary principle implies the existence of discretion with regard to those who are believed to breach it. According to Art. 21, this applies to private persons (e.g., food chain operators).

Additionally, in cases of non-contractual liability of individuals, that a rule such as the precautionary principle has been seriously breached must necessarily be proved. Whether the precautionary principle, an instrument of interpretation, may be practically applied is doubtful-it necessarily leaves the interpreter with a margin of discretion. The precautionary principle derives from contemporary scientific knowledge about the long-term consequences of presently doubtful situations, in which inertia may cause irreparable damages.

The attention the Court pays to evaluating the existing relationship between the discretion granted to Member States or Institutions and infringement of rules intended to confer rights on individuals should extend to the non-contractual liability of individuals as well.

Requiring private persons who exercise control over the food chain to respect the precautionary principle and, if the principle is breached, their noncontractual liability means assigning the role of protecting general EU interests to a private/civil tool.

Protection of the EU legal system and public-and not just economic-order is another objective which is ensured by recognizing non-contractual liability for infringement of the precautionary principle.

In contrast to Art. 101 of the Treaty on the functioning of the European Union, the precautionary principle and remedies for contracts have the same further function. In this situation, the EU legal system assigns to contract not only the role of self-regulation of private interests directly involved in it but also the function of guaranteeing the economic order sought by the EU.

Contractual liability and compensation for damages suffered: the guarantees in the EU legal system: In accordance with Art. 101, paragraph 1 of the Treaty on the functioning of the European Union (Art. 81 of the
EC Treaty) (conferral of rights of individuals), one can claim for damages caused by actions or contracts which may restrict or distort the competitive process.

The full effectiveness of such a disposition-and specifically the effectiveness of the prohibition established in paragraph 1-may be jeopardized if the domestic legal system does not render, because of distortion of competition, either practically impossible or excessively difficult an exercise of the rights conferred by Community law (the principle of effectiveness) (Courage v Crehan (C-453/99) [2001], ECR I-6297).

In the Manfredi judgements (Manfredi (C-295298/04), [2006] ECR I-6619), confirming the Court's reading of Courage v. Crehan, the Court of Justice pointed out that Art. 101, paragraph 1 of the Treaty on the functioning of the European Union produces direct effects on horizontal relationships and confers on individual rights which national courts must protect.

In protecting the economic order of the Community, the nature of Art. 101 of the Treaty on the functioning of the European Union legitimates anyone to rely on the invalidity of competition-restricting agreements and therefore seek remedy for damages suffered if a causal link may be established between the aforementioned agreements or practices and damages.

Anyone (not only businesses but also consumers) who suffers damages because of competition-restricting agreements can claim for damages (Corte di Cassazione, n. 2305/2007, (2007) for it., I, 1097).

The case laws of the Court of Justice on infringement of Arts. 101, 102 et seq., the Treaty on the functioning of the European Union (Arts. 81 and 82 of the EC Treaty), aimed at structuring and safeguarding the EU internal market, often combine claims for damages with those for absolute or relative nullity of competition-restricting contracts (Palazzo et al., 2008).

Protection for compensation guarantees that it would be in the weaker party's fundamental interests to preserve the contract if, as a compensatory measure, the terms of the contract are revised (Daniele, 1995).

The fundamental interests of the weaker party with regard to the contract may coincide with a desire not to maintain an unfair or unbalanced contract if the party suffers damages because of that contract. In this case, the remedy which most likely coincides with the weaker party's interest is a nullity action related to an action for damages, within the bounds of the negative interest.

Conversely, the weaker party may envisage maintaining a contract which infringed competition rules. Thus, the balance of the terms of the contract is guaranteed by an action for damages, which is based on 


\section{J. Social Sci., 8 (3): 381-389, 2012}

violation of rules intended to safeguard the internal market. In such cases, protection for compensation is not connected to any nullity action.

In this situation, the EU legal system assigns to the contract not only the role of self-regulation of interests of individuals directly involved in it but also a function of guarantee of the EU economic order. For this reason, contractual liability and actions for damages are measured to safeguard the EU economic order (The Queen v Ministry of Agriculture, Fisheries and Food, ex parte Hedley Lomas (Ireland), [1996], ECR, I-2553).

Non-wrongful conduct of Member States and the recovery of sums paid but not due: The wrongful conduct of Member States, as noted above, is limited by identifying an infringement of law.

To receive compensation for damages, infringement of rules by Member States and the EU must be sufficiently serious. Any presumed breach on the part of Member States and Institutions must extend seriously beyond the limits of their power so that a causal link exists between the breach and the damages. When the breach is not identified, the individual has, in any case, the right to recover sums paid but not due to Member States and Institutions.

With regard to the non-wrongful conduct of Member States or Institutions, one way of protecting the individual rights of EU citizens is the principle of unjust enrichment.

The action for recovery of sums paid but not due is another way to guarantee the effectiveness of rights within EU law and its supremacy.

In such cases, we explain the tendency of the Court of Justice to identify the Member States' right to receive sums on the basis of a national rule contrary to EU law. For example, it would be in contrast with the requirement for correct implementation of EU law if an individual paid a tax which was later proved to be incompatible with EU law (see San Giorgio, (C199/82), [1983], ECR, 3595) or paid sums on the basis of an unlawful (according to EU regulations) an act which has been altered or annulled (see ex multis Vreugdehil, (C- 282/90), [1992], ECR, 1937) and, in an opposite scenario, a Member State did not recover illegally granted state aid (Commission v Germany, (C70/72), [1973], ECR, 813).

In his opinion about Express Dairy Foods (Express Dairy Foods, (C-130/79), [1980], ECR, 1887) Advocate-General Capotorti asserts that the right to recover sums paid partially or completely unnecessarily but not due is a true subjective right of EU citizens. This right derives from a general principle common to the legal systems of all Member States.
In the recovery of sums paid but not due, the Court of Justice recognizes the nature of a remedy common in the European legal system (reimbursement of charges paid but not due) and applied in vertical and horizontal relationships For this reason, the Draft Common Frame of Reference (DCFR) contains a detailed description of recovery resulting from the termination of a contract or from any flaw in it. For example, the wrongful nature of sums which are the object of a contract and are indicated in it may give scope for a claim of infringement of Arts. 101, 102 et seq. Of the Treaty on the functioning of the European Union.

Thus, a typical principle of civil law such as the reimbursement of charges paid but not due achieves a specific purpose of the Community (whose right and supremacy would otherwise be frustrated). The aim of EU law would not be achieved if the effectiveness of the return of a sum received by a Member State because of a procedure adopted in violation of an EU law had not been ensured. The sum paid but not due would remain in the hands of the receiving Member State which, not being in a state of non-contractual liability, would keep for itself this sum of money collected in violation of an EU law. Again, the Member State which does not recover illegally granted state aid invalidates any judgement of the Court of Justice on the aforementioned aid-but not without consequences for, for example, competition in the EU internal market (Cippitani, 2007).

Protection through recovery of sums paid but not due is a tool for the effectiveness of EU law and the fulfillment of its purpose. Therefore, the EU has a particular interest in ensuring that the Member State in question reimburses on the charges regardless of whether they are paid or unimplemented and that it does not illegally recover the state aid granted. The Court of Justice must be aware that the completeness of this kind of protection and its effectiveness may be mitigated by the tendency of domestic legislation, especially in the field of fiscal law, to reduce or eliminate the requirement of the national government to pay sums perceived as not due.

Unimplemented Directives, relationships between private individuals and non-application: a control system at the discretion of Member States: In horizontal relationships, provisions for stakeholders to demand non-application of national legislation if it contrasts with EU law accompany individual rights. The only limitations we find in this case are those EU rules characterized by the effet utile. 


\section{J. Social Sci., 8 (3): 381-389, 2012}

Non-application in relationships between private individuals does not accompany unimplemented Directives. However, with the expansion in the EU's powers, we cannot exclude the possibility that, in relation to the legal position of individuals in interrelationships dependent on unimplemented Directives, these Directives cannot achieve a horizontal effect. Certain judgements of the Court of Justice may be interpreted in this sense (see Marshall (C-152/84) and Arcaro (C-186/95), [1996] ECR, I-4705).

The Court has recognized some horizontal effects in one Directive not implemented in the United Kingdom's legal system: the rights of an employee against a Member State which was qualified not as a public authority but as a private employer (Foster (C188/89), [1990] ECR, I-3313).

In another case, the Court of Justice did not apply German law to an employment contract between Werner Mangold and Rüdiger Helm: the national law did not ensure the full effectiveness of the general principle of equal treatment for work done by men and women on the grounds of age, during the period in which the transposition of Directive 1999/70/EC had not expired (Werner Mangold v Rüdiger Helm (C144804), [2004], ECR, I-9981).

These anomalous cases and their reasons may be explained by referring to the criteria governing nonapplicable. In horizontal relationships, they assume special connotations.

The reference here is to Unilever Italia $\mathrm{SpA} v$ Central Food SpA (Unilever Italia SpA v Central Food SpA, (C-443/98), 2000] ECR, 1-7535), which involved a law applicable to relationships between private individuals (see again Unilever Italia $\mathrm{SpA}$ v Central Food SpA, (C-443/98), cited). The question referred to technical standards and regulations (CIA Security International SA v Signals on SA and Securitel SPRL (C-194/94), [1996], ECR, I-220, particular, paragraphs 11 and 12. see also to Commission v Germany (C317/92), [1994], ECR, I-2039, paragraph 26) and their direct applicability in civil proceedings between individuals (concerning contractual rights and obligations) when they are contained in unimplemented Directives.

The Court of Justice answered the questionsubmitted in a preliminary ruling-stating that, in civil proceedings, a national court must refuse to apply a national technical regulation which was adopted during a period of postponement of adoptions prescribed in Art. 9 of Directive 83/189/EC. Arts. 8 and 9, cited, are technical standards and regulations.

The Court of Justice, according to its case law, in which an unimplemented Directive cannot impose obligations on an individual and cannot therefore be relied against an individual, could not apply it in Unilever Italia Spa v Central Food Spa. Noncompliance with Arts. 8 and 9 of Directive 83/189/EC constitute a substantial procedural defect and renders inapplicable a technical regulation adopted in breach of those Articles.

The Court, therefore, stated that its case law on the prohibition of horizontal effects (rights or obligations for individuals) by unimplemented Directives cannot be applied when the infringement of a Directive constitutes a substantial procedural defect.

Non-transposition Directives that define the substantive scope of a legal rule create rights or obligations of individuals and the national court must decide the case before it on this basis (Faccini Dori (C91/92), cited, paragraph 20). This may happen before the infringement by a Member State of a general principle of the EU legal system as well, in a Directive the period for transposition of which has not expired.

In the Unilever judgement, the technical regulation adopted in breach of Art. 9, cited, had an effect on the free movement of products as well (Unilever Italia Spa v Central Food Spa (C-443/98), cited, paragraphs 50 and 51).

These judgements, which appear to show a trend differs from the Court's settled case law on Directives (see, e.g. Faccini Dori), are a clear indication of the meaning of non-application of national law in contrast with the effet utile of a Directive.

When, in implementing EU rules, the discretion of a Member State is not considerable or, rather, is completely reduced (as in technical standards and regulations) or when it does not allow changes as a general principle, national legislation contrary to a Directive for which the period for transposition has not expired need not compulsorily be applied.

In these cases, Member States cannot implement a Directive and alter the situation, because their discretionary powers with regard to the implementation of technical regulations, such as in the Arts. 8 and 9, cited, is not considerable.

This statement about horizontal relationships confirms the conclusions about non-application in relationships between private individuals and Member States (vertical relationships): non-application is a check on the discretion of the State in question.

Except in the conditions mentioned above, the legal protection of non-application does not apply when the EU law is characterized by the effet utile. In these cases, judges are obliged to interpret national law in conformity with EU law (Oliver and Roth, 2004). 


\section{J. Social Sci., 8 (3): 381-389, 2012}

Additionally, in horizontal relationships, national courts apply national law partly through interpretations derived from EU Law.

Unimplemented Directives, which cannot produce direct effects between individuals, may render immune from non-contractual and contractual liabilities individuals who are engaged in behavior which, although not permitted by national law, is provided for in an unimplemented Directive (Marleasing SA v La Comercial Internacional (C-106/89), [1990], ECR, I4135, paragraph 9).

When the moment for implementing a Directive has expired and the result prescribed by that Directive is not obtainable by the Member State or by interpreting the national law in conformity with EU law, it is possible, in appropriate conditions, to invoke the noncontractual liability of the Member State, as described above (Faccini Dori (C-91/92), [1994] ECR I-3325, paragraphs 26, 27, 28, 29, 30).

\section{CONCLUSION}

Many theories have been posited to describe the pattern of economy regulated by the government. These include the 'public interest' theory and several versions of the 'interest group' or 'capture' theory (Posner, 1974; Zingales, 2004; Shleifer, 2005). The traditional public law tools for market regulation were listed as state ownership, public franchising, or licensing or as the more common forms of regulation which rely on semiprivate bodies or independent regulatory agencies for standard making or market controls. Additionally, they can include various and still experimental forms of self-regulation by means of voluntary arrangements on the other end of the scale.

However, in the European legal system, private and public law may be seen as two distinct regulatory strategies of the EU and national markets; however, the instruments for rectifying market failures and guaranteeing the economic order sought by the EU range across public and private laws.

This combination of different regulatory strategies must be simultaneously employed to stimulate the design an integrated European market and provide the reasons for its failures. Consequently, 'the variety of means available to achieve these goals-which range from traditional public law tools such as state ownership, public franchising or licensing, through the more familiar forms of regulation (...), to various and still experimental forms of self-regulation by means of voluntary arrangements on the other end of the scalecall for a general framework in order to avoid conflicts, incoherence or redundancy between regulatory approaches' (Cafaggi and Watt, 2009).

Thus, like the traditional system of economic regulation, the EU legal system-thanks to the multilevel dimension of European private law-has been characterized by the use of new complementary/alternative ways to govern its market integration, in place of the old method of legislative harmonization realized through institutional instruments.

Familiar private law instruments such as tort or contract now appear as only a small part of many possible tools harnessed with the aim of obtaining allocative efficiency or distributive justice and are synthetically described as the correction of market failures (e.g., The law rules applying to contracts for services, EC environmental law, environmental liability, product safety, product liability).

Usually, arrangements for available public regulatory tools are extremely diverse. Private law offers complementary remedies in individual situations through contract law and, most importantly, consumer law in the case of information problems. Additionally, in the manner of tort law, private law assumes the effects of externalities suffered by third parties. Tort law may give ex post situational remedies as well, in case one party has been seriously underprivileged.

However, the choice of using private rules is usually different from that of using public rules, which include licensing, prohibition or prior authorization and quality standards and mandatory disclosure and could potentially be accompanied by administrative or criminal sanctions. On the other hand, the use of private transaction rules exposes the sector to possible speculative pressures usually affecting the market segments in which financial intermediation plays a crucial role (Amundsen et al., 2006).

'Social' regulation of private law (Joerges adn Petersmann, 2006) is correlated to distributive justice and the insufficient resources of that section of the public which cannot access essential services, to the greater bargaining power of the service provider, or to the inadequate financial and educational endowment of consumers to best measure their preferences. In the same area of the market, public ownership models based on tax-financed subsidies have usually been superseded by privatized models (Porta et al., 1996), in which a contractor may be contractually bound by a universal service obligation or at least an obligation to ensure that vulnerable groups enjoy the service at a lower tariff (Cafaggi and Watt, 2009). 


\section{REFERENCES}

Al-Swelmeen, M.M., 2006. The International law classification as an understanding of the built of international law. J. Soc. Sci., 2: 104-1070. DOI: 10.3844/jssp. 2006.104.107

Amundsen, E.S., F.M. Baldursson and J.B. Mortensen, 2006. Price volatility and banking in green certificate markets. Environ. Resource Econ., 35: 259-287. DOI: 10.1007/s10640-006-9015-1

Bartolini, A., 2005. Il Risarcimento Del Danno Tra Giudice Comunitario e Giudice Amministrativo. La Nuova Tutela Del c.d. Interesse Legittimo. 1st Edn., Giappichelli, Torino, ISBN-10: 8834854853, pp: 274.

Cafaggi, F. and H.M. Watt, 2009. The Regulatory Function of European Private Law. 1st Edn., Edward Elgar Publishing, Cheltenham, ISBN-10: 1847201997, pp: 345.

Cippitani, R., 2007. I Contratti e Le Obbligazioni, in (a Cura Di) A. Palazzo, A. Sassi, edit by Diritto Privato Del Mercato. 1st Edn., Perugia, pp: 154.

Daniele, L., 1995. Tendenze Attuali Della Giurisprudenza in Merito Alla Nozione Di Norme Direttamente Efficaci. 1st Ednm., Dir. Com. E Scambi Internaz, pp: 226.
Gerven, V.W.V., 1993. Non-Contractual Liability of Member States, Community Institutions and individuals for Breaches of Community Law with a View to a Common Law for Europe. Maastricht Jour. Eur. Comp. Law.

Joerges, C. and E.U. Petersmann, 2006. Constitutionalism, Multilevel Trade Governance and Social Regulation. 1st Edn., Hart, Oxford, ISBN-10: 1841136654, pp: 554.

Oliver, P. and W.H. Roth, 2004. The internal market and the four freedoms. Comm. Mark Law Rev., 421: 407-407.

Palazzo, A., A. Sassi and F. Scaglione, 2008. Permanenze Dell'interpretazione Civile. 1st Edn., ISEG, Perugia, ISBN-10: 8895448022, pp: 464.

Porta, R.L., F. Lopez-de-Silanes, A. Shleifer and R.W. Vishny, 1996. Law and finance. J. Political Econ., 106: 1113-1155.

Posner, R.A., 1974. Theories of economic regulation. Bell J. Econ. Manage. Sci., 5: 335-358.

Shleifer, A., 2005. Understanding regulation. Eur. Finan. Manage., 11: 439-451. DOI: 10.1111/j.1354-7798.2005.00291.x

Zingales, L., 2004. The costs and benefits of financial market regulation. University of Chicago. 